\title{
Grammatical Errors Found in English Writing: A Study from Al-Hussein Bin Talal University
}

\author{
Khitam Mohameed Alghazo ${ }^{1} \&$ Mohamed Khaliefah Alshraideh ${ }^{1}$ \\ ${ }^{1}$ College of Science Education, The Curriculum and Instruction Department, AL-Hussein Bin Talal University, \\ Jordan
}

Correspondence: Khitam Mohameed Alghazo, College of Science Education, The Curriculum and Instruction Department, AL-Hussein Bin Talal University, P.O. Box 20, Maan, Jordan.

Received: March 13, 2020

Accepted: May 21, $2020 \quad$ Online Published: August 24, 2020

doi:10.5539/ies.v13n9p1

URL: https://doi.org/10.5539/ies.v13n9p1

\begin{abstract}
This study investigated the frequent grammatical errors, found in the writings of Arab students' taking English writing courses in AL-Hussein Bin Talal University Learners' errors were considered positively as the best sources to identify students' limitations in English writing. Therefore the present study intended to investigate the grammatical errors of Arab students' writings in English in AL-Hussein Bin Talal University and to see if there are any differences in the grammatical errors according to year of study. To conduct this study data was collected from the writing sessions of writing classes that were taught during the fall semester of 2019. The data was collected, analyzed and categorized from students, all majoring in English Language and Literature and ranging from freshman to seniors. A Grammar test Questionnaire designed by the researchers was distributed to the students in these writing sessions. The results showed that the most frequent grammatical error was with the verb tense on a mean of (3.75), followed by errors in the article on a mean of (3.62), wrong word order on a mean of (3.57), noun ending on a mean of (3.40) and least was sentence structure on a mean of(3.39). The results also showed that the seniors on the grammar test on all its parts did better than the freshmen, juniors and sophomores that are the least problems were found among the seniors.
\end{abstract}

Keywords: Alhussein Bin Talal university students, English writing, grammar errors, sophomores

\section{Introduction}

Learning a second language depends on learning the skills of listening, speaking reading and writing. These four skills allow the student to comprehend, produce and use the language in effective interpersonal communication. They are most often acquired in the order of listening, speaking, reading and writing. Listening and reading are called passive skills because learners do not need to produce language to do these, they receive and understand it. Speaking and writing are called active skills because learners doing these need to produce language (Ramadan, 2019).

\subsection{Writing Skill}

The most difficult of all these four skills is the writing skill. Writing skill is considered as the most difficult task for students because they are not proficient in the language and do not have good mastery of vocabulary and grammar. They have limited exposure to the language and seldom communicate using the language in daily life. For students to become good in the writing skill they must become good in their native language first (Atashian \& Al-Bahri, 2018; Zerin, 2007). Teachers teach the students how to form a sentence in Arabic without putting it in context (deductive) the aim is only learning the grammatical rule. Therefore the student will not be able to apply it in his/her writing. How can we ask the students to write in English if he can't in Arabic? Usually English is taught and explained in Arabic that also causes students to have problems (Al Noursi, 2018; Marek, 2016; Khan, 2011). Even though the textbooks in the curriculum take into consideration all the skills but the problem is in the teacher and the environment. Students might learn English in the classroom even though mainly it is in Arabic but still they will not find the right environment to practice it (Kresh, 2009). All will result in students' weakness in the different skills of the language and especially in the writing skill since it is an accumulative of all the other three skills.

The major problem in students writing is Grammar. Grammar errors occur in the writing of almost all non-native students (Abdulkareem, 2013). Grammar errors rarely occur in native speakers' writing (Kraichoke, 2017) but 
very commonly do in the work of less proficient ESL students, whose mother-tongue "interferes" with the production of correct English. Nonnative speakers make numerous mistakes in the use of verbs (for example, incorrect tense choice, incorrect tense form), the articles ( $\mathrm{a} / \mathrm{an}$, the particularly students in whose languages these words do not exist), and word order (Frankfurt international school, 2018; Nonkukhetkhong, 2013).

The most common errors among these students usually include noun ending errors which include plural or possessive ending incorrect i.e. the book were heavy; their name is joe and mike, omitted, or unnecessary, includes relevant subject-verb agreement errors i.e. she write, another article errors which include article or other determiner incorrect i.e. an orange, omitted, or unnecessary, verb error (verb tense or verb form) i.e. he play football yesterday, All errors in verb tense or form, including relevant subject-verb agreement errors, also wrong word which include all specific lexical errors in word choice or word form, including prepositions and pronoun errors and last sentence structure which also includes errors in the sentence clause boundaries (run-ons, fragments, comma splices), word order, omitted words or phrases, other unidiomatic sentence construction (Ferris \& Roberts, 2001; Clark, 2007).

Arab students learning the English language as a second language tend to carry much of the Arabic structure. In dealing with the verb to be for example what happens is that "verb to be" is not used in the present tense, and no auxiliary "do " and furthermore, there is a single present tense in Arabic, as compared to English, which doesn't have the simple and continuous forms. What an Arabic speaker does is he would say, "I boy" instead of saying, "I am a boy". Another example saying "she woman" rather then, "she is a woman" and so on (BaSaeed, 2013). You can see from the examples given how the verb to be is deleted. Also the Arabic language doesn't use the present perfect tense so the students would say "I completed my paper, can you see it? Another problem in Arabic language is that it doesn't have model verbs which also cause grammatical mistakes (Jenwitheesuk, 2009; Shoebottom, 2007). Native language clearly affects learning the target language, especially at the beginning stages of acquiring it, while students rely on the grammar of their native languages to overcome any difficulties. However, this method does not always work because English and Arabic have huge differences in grammar.

Another area of grammar is adjectives. In Arabic the structure of the adjective is that it comes after the noun, this leads Arab students to make word order mistakes in written or spoken English, so when Arab students speak they tend to say "girl tall" rather than saying "tall girl", "boy thin" rather the "thin boy" and so on. This kind of structure is carried when speaking in English and therefore leads to grammatical problems (Dahami, 2012). The pronoun is another problem in English it is deleted or omitted but in Arabic it requires the pronouns in relative clauses, this also causes grammatical mistakes such as saying "where is the book which I leant it to you last week?" There are so many other problems such as genitive constructions, indefinite articles since it doesn't exist in Arabic which leads our students to omit it when writing in English, sentence structure, word order, and so many more (Alasfour, 2018). All the mentioned differences between the two language cause errors among students and that is a problem.

\subsection{Problem of the Study}

The researchers have noticed that students majoring in English have great problems when it comes to grammar, and they have realized that students commit so many grammatical errors in their writings, which make their writings unreadable, therefore sought to seek this research.

\subsection{Research Questions}

The current study was guided by the following questions:

1) What are the most frequent errors in the writings of students in Alhusssein Bin Talal University?

2) Do the grammatical errors differ according to year of study?

\subsection{Importance of the Study}

The researchers believe that identifying the different grammatical errors students commit in their writing will help both the students and the teachers. It will help students in that it will become a guide to help them avoid grammatical errors in their future writings. And as for the teachers it will become an input as consideration in reviewing the grammar materials especially the common errors.

\section{Literature Review}

Writing is constructed by putting sentences in sequence, one after another and it should be understandable. Meaning of the sentence should flow from one sentence to the next, carrying the argument or point of view forward in a clear and concise manner. If you do not use correct grammar in your writing, it will become hard on the reader to follow the text because the flow of meaning is interrupted.In writing the student needs to be 
accurate in grammar to be able to form good correct grammatical sentences (Effendi et al., 2017; Al-Srdawy \& Zeidan, 1988).

Many studies have been done on the grammatical errors in writing. There are those that have focused on the ESL writing process such as the studies done by (Cambria \& Guthrie, 2010; Khwaileh, 1999; Harushimana, 1999) other studies focused on the writing process among EFL students such as (El-Aswad, 2002; Mahfoudhi, 2003) and other studies worked on comparing between writing in the students native language and writing in the target language such as the studies done by (Al-Amer, 2001; El-Mortaji, 2001). And following are a number of studies that have touched somewhat on the writing process.

Alfaqiri (2018) conducted a study to explore the writing difficulties and challenges that Saudi Arabian English as a second language learners experience at different levels of proficiency. The participants of the study consisted of 114 Saudi Arabian students between the ages of 15 and 36 (53 female, 61 male).The research questions not only focused on understanding the challenges presented to the students, but, also, the metacognitive strategies that the students used to solve these challenges. The results showed that the participants lacked experience in writing English and, as such, experienced grammar issues.

A study done by Sönmez and Griffiths (2015) examining the grammar errors in written work made by 30 freshman students in the English Language Teaching Department at a Turkish university. The students were divided into two groups (each consisting of 15 students), with one group at a higher level than the other, according to the results of their proficiency exam. The students' written work was marked and the grammar errors were noted down. An analysis of the errors revealed the following error types were: plurality, articles, subject-verb agreement, word order and pronouns.

A study by Nonkukhetkhong (2013) investigated grammatical errors made by first year English major students at Udon Thani Rajabhat University. The errors found were verbs, nouns, possessive case, articles, prepositions, adjectives, adverbs, sentence structure, ordering. A similar study was conducted by Ghabool, Edwina, and Kashef (2012) and revealed that Malaysian ESL students have problems in writing, especially in language use (grammar) and punctuation. Another study was done by Abushihab, El-Omari, and Tobat (2011), during an investigation into the written grammatical errors of Arabic students of English as a foreign language at a university in Jordan, discovered that most of the students' errors related to prepositions (26\%), followed by morphological errors, articles, verbs, use of active/passive and tenses.

Fageeh (2004) conducted a study on 34 male Saudi English major college students' beliefs regarding their English writing difficulties using interviews, observations and text analysis. Results of the study showed that Arab students used Arabic to develop their ideas and rehearse their English text and also they used to write the text in Arabic and then translate it into English and therefore students encountered problems in spelling, vocabulary and grammar in their writings. Another comparative study conducted by Alnofal (2004) on Arabic first language writing and English second language writing processes on a sample of 161 male and 42 female undergraduate students using online survey and Rose's writers Block test narrative task stimulated recall interviews. The results showed that Arab students seem to be influenced by their experience in their first language (Arabic) and therefore they tend to make more formal grammatical and spelling errors when writing in English than in Arabic. Also a study done by Elhami and Altaha (2000) was done to check the errors made by Saudi students in both their production and recognition of grammatical structures in English. The results showed that the number of errors that Saudi students make in production is higher than that in recognition. This means that Saudi students are less competent in grammatical production than in grammatical recognition. Another study was carried out by a number of ESL teachers on their ESL students where they got them to write in journals since journals help ESL student on different levels. Teachers have done this in order to help students improve their writings since they make a great deal of spelling and grammatical mistakes. Students usually find it easier for them to try to express themselves in writing rather than in speaking. Therefore journals can help them improve their mistakes (Spack \& Sadow, 1983).

\section{Method}

In order to arrive at the purpose of this study, the researchers selected three writing sessions for the study sample during the academic year of 2019, the writings from these sessions were collected and linguistically analyzed and evaluated by the researchers and some English Language professors before it was statistically analyzed.

\subsection{Study Sample}

The study sample consisted of three writing sessions in AL-Hussein Bin Talal University during the fall semester of 2019. A total of 87 students participated in the study (39) male students and (48) female students all majoring 
in English Language and literature, ranging from freshmen to seniors: Freshmen students (14), juniors (18), sophomores (32) and seniors (23). So the researchers here depended on using convenience sampling, because the subjects were chosen simply because they are the easiest to obtain for the study.

\subsection{Procedures}

The data was collected during the sixth week of the Fall semester 2019. The analysis of the students' written work errors was done in several steps: The researchers started by collecting data, which was the students' written work. The second step was to identify the grammatical errors found in the students' writings and that was done with the help of checklists in order to classify different types of errors made by the respondents. The third step was the classification of these errors in the categories of Verb error (VT), Article Errors (ART), Wrong Word (WW), Noun Ending Errors (NE) and Sentence Structure (SS), these were the main categories that appeared through the analysis. Fourth, the researchers gave their analysis to a group of English Language professors who revised, edited and supervised it. Finally a questionnaire was designed to include these categories with a number of sentences following each category.

\subsection{Instrument}

The instrument used in this study was designed by the researchers. It consisted of two parts: the first contains general information about the participants: gender, and year of study. The second part is a questionnaire to measure the grammatical errors found among the participants which were Verb error (VT), Article Errors (ART), Wrong Word (WW), Noun Ending Errors (NE) and Sentence Structure (SS).

The questionnaire consisted of 30 items distributed on five areas of grammatical errors which include 6 items on each.

\subsubsection{Reliability and Validity of Instrument}

To make sure of the validity of the questionnaire designed, it was given to a number of the faculty members in the English department in Alhussein Bin Talal University. None of the faculty members gave any comments on adding or deleting anything in the instrument. So the researchers depended on using content validity in order to ensure the questionnaires' validity.

And to check its reliability, in order to achieve the goals of this study, the instruments were distributed on a population of fifty (32) students who were not included in the study at hand, and that was done by doing Cronbach Alpha $(\alpha)$ for the grammatical errors used in the instrument.

Table 1. Cronbach alpha for the grammatical errors used in the instrument

\begin{tabular}{cc}
\hline Areas & Cronbach Alpha \\
\hline Verb error (VT) & 0.74 \\
Article Errors (ART) & 0.77 \\
Wrong Word (WW). & 0.82 \\
Noun Ending Errors (NE) & 0.79 \\
and Sentence Structure (SS) & 0.86 \\
Total & 0.91 \\
\hline
\end{tabular}

\section{Results}

The data was entered on the SPSS program and the results of the means and standards deviation and One Way ANOVA were calculated for the Grammar questionnaire.

In order to answer the first research question of the study which states "What are the most frequent grammatical errors in the writings of students in Alhusssein Bin Talal University" the means and standard deviations of the grammatical errors were done and ordered as shown in Table 2. 
Table 2. Means and standard deviations of grammatical errors found among students

\begin{tabular}{ccc}
\hline Error Type & Means & SD \\
\hline Verb error(VT) & 3.75 & 1.62 \\
Article Errors(ART) & 3.62 & 1.42 \\
Wrong Word(WW) & 3.57 & 1.54 \\
Noun Ending Errors(NE) & 3.40 & 1.23 \\
Sentence Structure(SS) & 3.39 & 1.34 \\
\hline
\end{tabular}

The results in Table 2 shows that the most frequent grammatical error was with the verb tense on a mean of (3.75), followed by errors in the article on a mean of (3.62), wrong word order on a mean of (3.57), noun ending on a mean of (3.40) and least was sentence structure on a mean of (3.39).This agrees with a study done by Li et al. (2016) on Grammatical Mistakes in College English Writing: Problem Analysis, Reasons and Solutions, and they found that students make mistakes in verbs, nouns, articles, sentence structure and more. It also agrees with the study done by Leman (2014) on finding the Common grammatical errors in students writing .his results showed that students make mistakes in word order, article, subject very agreement, verb tense and more. Also Sawalmeh and Hassan (2013) analyzed written English essays of preparatory students in Saudi Arabia. He analyzed 32 essays of written by 32 Arabic-speaking Saudi learners of English. All of the errors in essays were identified and classified into different categorizations. The results showed that the Arabic speakers in this study committed ten common errors. These errors were: verb tense, word order, singular/plural form, subject verb agreement, double negative, spellings, capitalization, articles, sentence fragments and prepositions. He found out total of 1422 errors. The most predominant errors were Verb tense agreement $235(16 \%)$, word order $156(10 \%)$, subject/verb agreement 1114 (8.2\%).

To answer the second research question which states "Does the grammatical errors differ according to year of study?" both means and standard deviations were done as shown in Table 3 below.

Table 3. Means and standard deviations of grammatical errors found among students according to year

\begin{tabular}{ccccccccc}
\hline Year of Study & \multicolumn{2}{c}{ Freshmen } & \multicolumn{2}{c}{ Juniors } & \multicolumn{3}{c}{ Sophomores } & \multicolumn{2}{c}{ Seniors } \\
\hline Grammatical Errors & Mean & SD & Mean & SD & Mean & SD & Mean & SD \\
\hline Verb error(VT) & 4.9 & 1.2 & 3.9 & 1.8 & 3.8 & 1.4 & 2.6 & 1.6 \\
Article Errors(ART) & 4.6 & .63 & 4.0 & 1.2 & 3.6 & 1.1 & 2.3 & 1.0 \\
Wrong Word(WW) & 4.7 & .91 & 3.7 & 1.2 & 3.5 & 1.0 & 2.1 & 1.1 \\
Noun Ending Errors(NE) & 4.0 & .96 & 3.7 & 1.0 & 3.6 & 1.1 & 2.3 & 1.1 \\
Sentence Structure(SS) & 3.9 & .73 & 3.8 & 1.3 & 3.7 & 1.3 & 2.2 & .95 \\
Total & 3.7 & 1.6 & 3.6 & 1.4 & 3.5 & 1.5 & 3.3 & 1.3 \\
\hline
\end{tabular}

It is clear from Table 3 above that there are statistical differences in the grammatical errors found among students according to year in favor of the seniors who made the least errors. The seniors did better than the freshmen, juniors and sophomores in the grammatical errors in all types as shown above. This could be due to the fact that seniors are in their fourth year and last year of study and that could mean that they have taken so many courses which helped develop their English language skills and therefore were better than the freshman, juniors and sophomores. In order to see if these statistical differences are significant a One Way ANOVA test for the means of the study participants on the grammatical errors according to year of study were done as shown in Table 4 below. 
Table 4. One way ANOVA for the means of the study participants on the grammatical errors according to year of study

\begin{tabular}{|c|c|c|c|c|c|c|}
\hline Grammatical Errors & Source & Sum of Squares & $\mathrm{df}$ & Mean Squares & $\mathrm{F}$ & Sig. \\
\hline \multirow{3}{*}{ Verb error(VT) } & $\begin{array}{c}\text { Between } \\
\text { Groups }\end{array}$ & 37.436 & 3 & 12.479 & 5.069 & .003 \\
\hline & Within Groups & 204.311 & 83 & 2.462 & & \\
\hline & Total & 241.747 & 86 & & & \\
\hline \multirow{3}{*}{ Article Errors(ART) } & $\begin{array}{c}\text { Between } \\
\text { Groups }\end{array}$ & 56.888 & 3 & 18.963 & 13.384 & .000 \\
\hline & Within Groups & 117.595 & 83 & 1.417 & & \\
\hline & Total & 174.483 & 86 & & & \\
\hline \multirow{3}{*}{ Wrong Word(WW) } & $\begin{array}{c}\text { Between } \\
\text { Groups }\end{array}$ & 67.083 & 3 & 22.361 & 13.431 & .000 \\
\hline & Within Groups & 138.182 & 83 & & & \\
\hline & Total & 205.264 & 86 & & & \\
\hline \multirow{3}{*}{ Noun Ending Errors(NE) } & $\begin{array}{c}\text { Between } \\
\text { Groups }\end{array}$ & 33.111 & 3 & 11.037 & 9.366 & .000 \\
\hline & Within Groups & 97.808 & 83 & & & \\
\hline & Total & 130.920 & 86 & & & \\
\hline \multirow{3}{*}{ Sentence Structure(SS) } & $\begin{array}{c}\text { Between } \\
\text { Groups }\end{array}$ & 43.625 & 3 & 14.542 & 10.673 & .000 \\
\hline & Within Groups & 113.088 & 83 & & & \\
\hline & Total & 156.713 & 86 & & & \\
\hline \multirow{3}{*}{ Total } & $\begin{array}{c}\text { Between } \\
\text { Groups }\end{array}$ & 1680.123 & 3 & 560.041 & 15.777 & .000 \\
\hline & Within Groups & 2946.314 & 83 & & & \\
\hline & Total & 4626.437 & 86 & & & \\
\hline
\end{tabular}

Table 4 above shows that there are significant statistical differences at the level of $(\alpha=0.05)$ on all the grammatical errors, to determine the differences between the year of study Freshmen, Juniors, Sophomores and Seniors, Scheffe test was done as shown in Table 5 below.

Table 5. Scheffe test results for the differences between the study participants on the grammatical errors found according to year of study

\begin{tabular}{cccccccccc}
\hline Year of Study & \multicolumn{2}{c}{ Freshmen } & \multicolumn{2}{c}{ Juniors } & \multicolumn{2}{c}{ Sophomores } & \multicolumn{2}{c}{ Seniors } \\
\hline Grammatical Errors & Mean & Sig & Mean & Sig & Mean & Sig & Mean & Sig \\
\hline Verb error(VT) & 4.9 & 1.81 & 3.9 & 1.81 & 3.8 & .328 & 2.6 & .000 \\
Article Errors(ART) & 4.6 & .592 & 4.0 & .592 & 3.6 & .231 & 2.3 & .000 \\
Wrong Word(WW) & 4.7 & .91 & 3.7 & 1.2 & 3.5 & 1.0 & 2.1 & 1.1 \\
Noun Ending Errors(NE) & 4.0 & .954 & 3.7 & .954 & 3.6 & .807 & 2.3 & .001 \\
Sentence Structure(SS) & 3.9 & 1.00 & 3.8 & 1.00 & 3.7 & .957 & 2.2 & .001 \\
Total & 3.7 & .604 & 3.6 & .604 & 3.5 & .386 & 3.3 & .000 \\
\hline
\end{tabular}

*Statically significant at $\alpha<0.05$.

Table 5 above shows that there are significant statistical difference at the level of $(\alpha=0.05)$ between the year of study in favor of the seniors. The means for this group was (3.3), for the Sophomores (3.5), for Juniors (3.6) and for the Freshmen (3.7).This result agrees with a study done by Sönmez and Griffiths (2015) who conducted a study on the grammar errors in written work made by 30 students in the English Language Teaching Department at a Turkish university. The students were divided into two groups (each consisting of 15 students), with one group at a higher level than the other, according to the results of their proficiency exam. The students' written work was marked and the grammar errors were noted down. An analysis of the errors revealed the following error types: plurality, articles, subject-verb agreement, word order, pronouns, prepositions, part of speech, auxiliaries, negation, tense agreement and lexis. Of these, most errors were made overall with parts of speech, plurality, 
subject-verb agreement, prepositions and articles. Although, as might have been predicted, the students in the lower group made more errors (the average of 3.5) than those in the higher group (the average of 2.8).

\section{Limitations}

The results of the current study are determined by a number of determinants that may hinder the generalization of its results.

Objective limits: The study was limited to studying the Grammatical Errors found in English Writing: A study from Al-Hussein Bin Talal University.

Place limits: The study was applied in Al-Hussein Bin Talal University in the Kingdom of Jordan.

Time limits: The study was applied in the fall semester of the academic year 2019.

Sample size limits: The study was applied on students taking writing during the application of the study.

\section{Discussion}

The study aimed to investigate the grammatical errors of Arab students' writings in English in AL-Hussein Bin Talal university by identifying, and categorizing the grammatical errors in English essay writings among these students. The results showed that the seniors, on the grammar questionnaire did better than the freshmen, juniors and sophomores, This agrees with the study done by Sönmez and Griffiths (2015) and Bataineh (2005).But from the study and the many studies done on the grammatical errors among students it is obvious that Writing in a foreign language is not an easy task for either students or teachers. In order to be successful in the foreign language writing classroom, both the teachers and the students should be aware of the possible difficulties they can face.In order to be able to help their students, writing teachers should prepare themselves well to overcome these difficulties by means of effective and planned instructional strategies.

\section{Conclusion}

This research was meant to discover the types of grammatical errors dominantly found in the writings of Alhuseein Bin Talal University students. Based on the results, the most frequent errors were, with the verb tense on a mean of (3.75), followed by errors in the article on a mean of (3.62), wrong word order on a mean of (3.57), noun ending on a mean of (3.40) and least was sentence structure on a mean of (3.39).and regarding the errors of grammar made according to the year of study, the least errors made on all the grammatical errors were in favor of the seniors.

Derived from the results this study can help teachers to help students overcome many of the errors they have specially when they are aware of the grammatical errors the students commit, this will assist teachers to adopt and implement effective techniques and systems for language teaching which can simultaneously render students awareness of the differences of the two languages which usually causes such grammatical errors.

\section{Recommendations}

After conducting this study, a number of recommendations were suggested by the researchers, first students should be encouraged to pay more attention to their grammatical mistakes and that could be done though enriching their knowledge in English and differentiating between their first language's rules and the English language they learn. Also students should be encouraged to read more because this will help them in leaning more and reducing the grammatical mistakes. It is also recommended that iv students should be encouraged to examine their written texts and try to find out by themselves the grammatical errors and correct them.

\section{Future Research}

The study could be conducted on larger group and at different educational institutions to test the external factors which influence learner language performance. Also it can be conducted on participants from different ages. This allows comparison in grammatical errors in writings committed by Arab learners of English from different ages.

\section{References}

Abdulkareem, N. (2013). An Investigation Study of Academic Writing Problems Faced by Arab Postgraduate Students at University Technology of Malaysia. Theory and Practice in Language Studies, 3(9), 1552-1555. https://doi.org/10.4304/tpls.3.9.1552-1557

Abushihab, I., El-Omari, A., \&Tobat, M. (2011). An analysis of written grammatical errors of Arab learners of English as a foreign language at Alzaytoonah private university of Jordan. European Journal of Social Sciences, 20, 543-552.

Al Noursi, O. (2018). Effects of Arabic and English Speaking Teachers on High School Students' Writing Achievement. European journal of language teaching, 3. 
Al-Amer, A. S. (2001). The Effects of Word Processing Use on Textual Revision across Languages: Arabic as a First Language and English as A Second Language (ESL).

Alasfour, A. (2018). Grammatical Errors by Arabic ESL Students: an Investigation of L1 Transfer through Error Analysis. Dissertations and Theses, Paper 4551.

Alfaqiri, M. (2018). English Second Language Writing Difficulties and Challenges Among Saudi Arabian Language Learners. Journal for the Study of English Linguistics, 6(1), 24-36. https://doi.org/10.5296/jsel.v6i1.12740

Alnofal, A. (2004). Arabic First Language Writing and English Second Language Writing Processes: A Comparative Study.

Al-Srdawy, A., \& Zeidan, B. (1988). Developmental and Academic difficulties. Retrieved from http://www.lakii.com/vb/showthread.php?threadid=136490

Atashian, S., \& Al-Bahri, K. (2018). Towards Arab Students' Grammatical Errors in Academic Writing\& their Perceptions. Arab World English Journal (AWEJ). Proceedings of $1^{\text {st }}$ MEC TESOL Conference 2018. https://doi.org/10.24093/awej/MEC1.10

BaSaeed, E. (2013). An Approach for Teaching English Language Grammar to Arab Young Learners. IOSR Journal of Research \& Method in Education (IOSR-JRME), 1(2), 20-30. https://doi.org/10.9790/7388-0122030

Bataineh, R. (2005). Jordanian undergraduate EFL students' errors in the use of indefinite article. Asian EFL Journal, 7(1), 56-67.

Cambria, J., \& Guthrie, J. T. (2010). Motivating and engaging students in reading. New England Reading Association Journal, 46(1), 16-29. $\quad$ Retrieved from http://literacyconnects.org/img/2013/03/Motivating-and-engaging-students-in-reading-Cambria-Guthrie.pdf

Clark, B. (2007). Five Grammatical Errors That Make You Look Dumb. Retrieved from https://copyblogger.com/5-common-mistakes-that-make-you-look-dumb

Dahami, Y. (2012). Adjectives and their Difficulties in English and Arabic A Comparative Study. Journal of Education \& Psychological Sciences, 9(1).

Effendi, M. S., Rokhyati, U., Rachman, U. A., Rakhmawati, A. D., \& Pertiwi, D. (2017). A Study on Grammar Teaching at an English Education Department in an EFL Context. International Journal on Studies in English Language and Literature (IJSELL), 5(2), 42-46.https://doi.org/10.20431/2347-3134.0501005

El-Aswad, A. (2002). A Study of the L1 and L2 Writing Process and Strategies of Arab Learners with Special References to Third-Year Libyan University Students (Unpublished dissertation). The University of Newcastle upon Tyne, UK.

Elhami, A., \& Altaha, M. (2000). Grammatical production versus grammatical recognition. International Review of Applied Linguistics in Language Teaching, 38(2), 3. https://doi.org/10.1515/iral.2000.38.2.83

El-Mortaji, L. (2001). Writing Ability Strategies and Two Discourse Types: A Cognitive Study of Multilingual Moroccan University Students Writing Arabic (L1) and English (L2).

Fageeh, A. (2004). Saudi College Students Beliefs Regarding Their English Writing Difficulties.

Ferris, D. R., \& Roberts, B. (2001). Error feedback in L2 writing classes: How explicit does it need to be? Journal of Second Language Writing, 10, 161-184. https://doi.org/10.1016/S1060-3743(01)00039-X

Frankfurt international school. (2018). Understanding mistakes in written language.

Ghabool, N., Edwina, M., \& Kashef, H. S. (2012). Investigating Malaysian ESL students' writing problems onconventions, punctuation, and language use at secondary level. Journal of Studies in Education, 2(3), 131-143. https://doi.org/10.5296/jse.v2i3.1892

Harushimana, I. (1999). A Qualitative Case Study of African and Middle Eastern Scholars Writing in English: Self-Conceptions of Professional Writing Development.

Holt, S. (1997). Responding to Grammar Errors: Approaches to Teaching Non-Native English Speakers Across the Curriculum (pp. 67-76). San Francisco: Joss-Bass. https://doi.org/10.1002/t1.7008

Jenwitheesuk, T. (2009). A Study of Persisted Syntactic Errors in Writing of the 3rd Year Students of English for International Communication Program. Conference Proceedings: The Role of Universities in Hands-on 
Education. Retrieved from http://www.vijai.rmutl.ac.th/upload/doc/1005101641426.pdf

Khan, I. A. (2011). Learning difficulties in English: Diagnosis and pedagogy in Saudi Arabia. Educational Research, 2(7), 1248-1257.

Khwaileh, F. (1999). Composing and Revising at the Computer: A Case Study of Three Jordanian Graduate Students.

Kraichoke, C. (2017). Error Analysis: A Case Study on Non-Native English Speaking College Applicants' Electronic Mail Communications.

Kresh, S. (2009). Some reasons for the weakness of students in the English language. Retrieved from http://www.sal3m.com/?p=243

Leman, M. (2014). Common Grammatical Errors in Students' Writing at Man 1 Prepare. State University of Makassar, Indonesia.

Li, F., Ren, J., \& Zhao, H. (2016). Grammatical Mistakes in College English Writing: Problem Analysis, Reasons and Solutions. International Journal of Applied Linguistics and Translation, 2(3), 20-28. https://doi.org/10.11648/j.ijalt.20160203.11

Mahfoudhi, A. (2003). Writing Processes of EFL Students in Argumentative Essays: A Case Study. Review of Applied Linguistics, 139, 153-190. https://doi.org/10.2143/ITL.139.0.2003202

Marek, M. W. (2016). Research Study Manuscript Outline. Conference: Spring 2014 Technology Enhanced Language Learning-Special Interest Group (TELL-SIG) conference, At Taichung, Taiwan.

Noman, A., \& Yafai, L. (2000). Culture in the think Aloud Protocols in Six Yemeni Writers of English (Unpublished Dissertation). University of Wales, Cardiff, UK.

Nonkukhetkhong, K. (2013). Grammar Error Analysis of the First Year English Major Students, UdonThani Rajabhat University. Proceedings of the Asian Conference on Language Learning 2013 (pp. 117-126). Osaka: The International Academic Forum.

Ramadan, M. (2019). Basic Ideas and Techniques for Teaching the Four Language Skills. English Language Teaching \& Testing Guide (C) 2019/2020.

Sawalmeh, M. H. M. (2013). Error analysis of written English essays: The case of students of the preparatory year program in Saudi Arabia. English for Specific Purposes World, 14(40), 1-17.

Shoebottom, P. (2007). A guide to learning English. Frankfurt International School.

Sönmez, G., \& Griffiths, C. (2015). Correcting grammatical errors in university-level foreign language students' written work. Retrieved from http://ksj.pwsz.konin.edu.pl

Spack, K., \& Sadow, C. (1983). Student Teacher writing Journals in ESL Freshman Composition. TESOL Quarterly, 17(4), 575-593. https://doi.org/10.2307/3586614

Zerin, S. (2007). Teaching writing to young learners. BRAC University.

\section{Copyrights}

Copyright for this article is retained by the author(s), with first publication rights granted to the journal.

This is an open-access article distributed under the terms and conditions of the Creative Commons Attribution license (http://creativecommons.org/licenses/by/4.0/). 